\title{
Evaluation of chronic lymphocytic leukemia by oligonucleotide-based microarray analysis uncovers novel aberrations not detected by FISH or cytogenetic analysis
}

\author{
Kathryn A Kolquist ${ }^{1}$, Roger A Schultz², Marilyn L Slovak ${ }^{2,5}$, Lisa D McDaniel ${ }^{1,2}$, Theresa C Brown ${ }^{3}$, \\ Raymond R Tubbs ${ }^{4}$, James R Cook ${ }^{4}$, Karl S Theil ${ }^{4}$, Victoria Cawich², Caitlin Valentin², Sara Minier ${ }^{2}$, Nicholas J Neill ${ }^{2}$, \\ Steve Byerly², S Annie Morton², Trilochan Sahoo ${ }^{2,6}$, Blake C Ballif ${ }^{2}$ and Lisa G Shaffer ${ }^{2^{*}}$
}

\begin{abstract}
Background: Cytogenetic evaluation is a key component of the diagnosis and prognosis of chronic lymphocytic leukemia (CLL). We performed oligonucleotide-based comparative genomic hybridization microarray analysis on 34 samples with CLL and known abnormal karyotypes previously determined by cytogenetics and/or fluorescence in situ hybridization (FISH).

Results: Using a custom designed microarray that targets $>1800$ genes involved in hematologic disease and other malignancies, we identified additional cryptic aberrations and novel findings in 59\% of cases. These included gains and losses of genes associated with cell cycle regulation, apoptosis and susceptibility loci on 3p21.31, 5q35.2q35.3, 10q23.31q23.33, 11q22.3, and 22q11.23.

Conclusions: Our results show that microarray analysis will detect known aberrations, including microscopic and cryptic alterations. In addition, novel genomic changes will be uncovered that may become important prognostic predictors or treatment targets for CLL in the future.
\end{abstract}

Keywords: chronic lymphocytic leukemia, microarray, oligonucleotide, FISH, cytogenetics, chromosome aberration

\section{Background}

Chronic lymphocytic leukemia (CLL), the most common leukemia diagnosed in adults from Western countries, is characterized by a monoclonal population of mature activated B lymphocytes that usually express CD5+ and CD23+. However, the clinical features, disease course, and outcomes are highly variable. Most patients diagnosed with CLL can survive for many years, but in a subset of patients the course progresses more rapidly and is fatal despite aggressive treatment.

Currently, the diagnosis of CLL is made using histopathology; flow cytometry with a typical pattern of coexpression of CD5, CD23, CD20(dim), and surface Ig

\footnotetext{
* Correspondence: lisa.shaffer@perkinelmer.com

${ }^{2}$ Signature Genomic Laboratories, PerkinElmer Inc., 2820 North Astor Street, Spokane, WA, 99207, USA

Full list of author information is available at the end of the article
}

(dim); and chromosomal abnormalities detected by fluorescence in situ hybridization (FISH) probes and karyotyping. Conventional cytogenetics with karyotyping requires the use of an immunostimulatory $\mathrm{CpG}$-oligodinucleotide DSP 30 plus IL-2 cocktail to enhance the yield of detectable chromosome aberrations in CLL cells. This cell culturing process is costly, time consuming, and requires the clinical indication of CLL at sample submission. Alternatively, FISH has been used to detect specific prognostic chromosome markers in CLL using a panel of five to six probes. However, locus-specific FISH does not reveal the complete cytogenetic picture [1]. Prognostic markers, determined primarily using $\mathrm{FISH}$, include deletions of $13 \mathrm{q}, 17 \mathrm{p}$, and $11 \mathrm{q}$ and trisomy 12 . Most anomalies detected by cytogenetics in CLL are copy number gains and losses; translocations are rarely identified [2].
C Biomed Central

C 2011 Kolquist et al; licensee BioMed Central Ltd. This is an Open Access article distributed under the terms of the Creative Commons Attribution License (http://creativecommons.org/licenses/by/2.0), which permits unrestricted use, distribution, and reproduction in any medium, provided the original work is properly cited. 
Previously, clinicians waited until patients diagnosed with CLL progressed to a specific stage to initiate therapy. Rai et al. [3,4] and Binet et al. [5] created staging systems that, until the past decade, were the hallmark for defining disease extent, prognosis, and initiation of treatment of CLL patients. Although these systems were standard of care, they did not predict the disease course for early-stage disease. In the past decade, our understanding of the pathophysiology of CLL has changed significantly with discoveries such as somatic mutations in the immunoglobulin heavy chain variable region (IGHV) genes, which are associated with a good prognosis [6,7], and lack of $I G H V$ mutations and increased CD38 and ZAP-70 expression, which are associated with poor prognosis. Along with this has come a change in the way CLL has been approached therapeutically [8].

Microarray-based comparative genomic hybridization (aCGH) on neoplastic specimens has facilitated diagnosis and gene discovery with the ability to perform genome-wide investigations [7-18]. These array studies have shown concordance with the cytogenetic and FISH results. In addition, these studies demonstrated that appropriate microarray design can facilitate the detection of clinically relevant findings that would be missed using FISH panels. Although promising, most such microarray studies of CLL to date have been technically limited by the use of non-targeted BAC arrays $[8,9,11]$, CGH-based oligonucleotide arrays that have either been non-targeted $[10,19]$ or targeted to a relatively small subset of cancer genes or genomic regions $(\sim 15)$ associated with cancer $[16,20]$, or SNP-based, whole genome (non-targeted) arrays [21].

In a novel approach as compared to these previous array studies, we developed a $135 \mathrm{~K}$-feature oligonucleotide-based microarray specifically targeted to more than 1800 cancer genes and regions and evaluated 34 patients diagnosed with CLL to compare the performance of this array to that of chromosome analysis and FISH. Our results further support microarray analysis as a diagnostic tool to detect cytogenetic abnormalities associated with CLL. In addition to the detection of known chromosomal rearrangements, we identified cryptic and novel DNA alterations using aCGH.

\section{Results}

We tested 34 samples, which had been previously assessed by routine chromosome analysis and/or FISH, on a CGH-based microarray designed for detecting copy gains and losses associated with leukemia and lymphoma. Copy number alterations (CNAs) were identified in all 34 samples (Table 1). Ten of the cases had prior chromosome analysis, and all of these samples had an abnormal karyotype. By karyotype, the number of abnormalities detected ranged from 1 (trisomy 12) to 10 (complex with hypodiploidy) with an average number of 4 abnormalities detected per case. By comparison, among all 34 cases, the average number of abnormalities per case by microarray analysis was 4.4 . We identified additional cryptic and/or novel aberrations by aCGH in 20 of $34(59 \%)$ cases (Table 1$)$.

\section{Discussion}

\section{Common aberrations identified by microarray analysis}

Our results confirm prior studies that show the most common abnormalities found in CLL and identifiable by arrays are deletion of $13 \mathrm{q} 14.3$, trisomy 12 , deletion of $11 \mathrm{q} 22.3$ and deletion of $17 \mathrm{p} 13.1$.

The 13q14 region has been identified as a recombination hot spot [9] and includes the RB1, DLEU1, and DLEU2 genes and microRNAs MIR16-1 and MIR15A. Deletion of the $13 \mathrm{q} 14.3$ region distal to $R B 1$ is the most common chromosomal abnormality found in CLL [10], and the DLEU2/MIR15A/MIR16-1 locus has been shown to play a role in controlling the expansion of mature B cells by down-regulating the genes that control entry into the cell cycle [11]. Twenty-two cases had known deletions of 13q by karyotyping and/or FISH. Figure $1 \mathrm{~A}$ shows the 22 cases in which $13 \mathrm{q}$ deletions were detected by microarray analysis. Nineteen samples had a monoallelic deletion at 13 q14.3 ranging in size from 0.12 to $68.8 \mathrm{Mb}$, and three of the samples had a biallelic deletion of $13 \mathrm{q} 14.3$ ranging in size from 0.88 to $1.12 \mathrm{Mb}$. Of the 19 cases with monoallelic deletions, 15 had deletion of RB1, MIR15A, MIR16-1, DLEU2, DLEU1; two had deletion of DLEU2, DLEU1, MIR15A and $M I R 16-1$ without deletion of $R B 1$; and one had deletion of DLEU1, MIR15A and MIR16-1 without deletion of $R B 1$ or DLEU2. Case 23 had a $126-\mathrm{kb}$ deletion that did not include RB1, MIR15A, MIR16-1, DLEU2 or $D L E U 1$, although the deletion was seen in $29 \%$ of nuclei by FISH. Of the three biallelic deletions, two retained RB1 while MIR15A, MIR16-1, DLEU2 and DLEU1 were deleted, and one had biallelic deletion of MIR15A, MIR16-1, DLEU2, and DLEU1 and monoallelic deletion of RB1 (Figure 1B). Case 19 showed a complex and cryptic pattern with deletions of $13 q 13.3$ and $13 q 14.2 q 14.3$ and duplications of $13 q 14.11 q 14.12$, 13q14.3q21.1, 13q21.1q21.2, 13q21.2, 13q21.31q21.32 and $13 q 21.33 q 34$. Thus, our data and that of others[22] confirm that aCGH can delineate the sizes and complexities of 13q deletions better than conventional cytogenetic and FISH analyses. However, based on FISH analysis [23], there appears to be no difference in overall survival between patients with monoalleleic and bialleleic deletions. The precision gained in delineating breakpoints and the genomic content in regions of deletions using microarrays has the potential to uncover additional genomic variation in these patients that might be 
Table 1 Thirty-four samples validated on an oligonucleotide array designed for detection of aberrations in leukemia and lymphoma*

\begin{tabular}{|c|c|c|c|c|c|}
\hline Case & Karyotype & FISH & Concordant array results & $\begin{array}{l}\text { Discordant array } \\
\text { results }\end{array}$ & New findings by microarray \\
\hline 1 & NA & $\begin{array}{l}\text { LSI D13S319 96\% loss, } \\
\text { LSI } 13 \text { q34 normal, LSI } \\
\text { ATM normal, CEP } 12 \\
\text { normal, LSI p53 normal }\end{array}$ & $13 q 14.2 q 14.3(47,613,553-50,628,718) \times 1$ & NA & $22 q 11.23(22,674,846-22,723,991) \times 0$ \\
\hline 2 & NA & $\begin{array}{l}\text { LSI D13S319 77\% loss, } \\
\text { LSI } 13 \text { q34 normal, LSI } \\
\text { ATM normal, CEP } 12 \\
\text { normal, LSI p53 normal }\end{array}$ & $13 q 14.2 q 14.3(47,123,245-50,443,082) \times 1$ & NA & NA \\
\hline 3 & NA & $\begin{array}{l}\text { LSI D13S319 81\% loss } \\
(34 \% \text { mono, } 47 \% \text { bi), LSI } \\
13 q 34 \text { normal, LSI ATM } \\
\text { normal, CEP } 12 \text { normal, } \\
\text { LSI p53 normal }\end{array}$ & $\begin{array}{l}13 q 13.3 q 14.3(36,736,548-51,816,512) \times 1 \\
13 q 14.3(49,315,855-50,237,971) \times 0\end{array}$ & NA & $\begin{array}{l}15 q 11.2(19,129,891-19,224,501) \times 3 \\
18 p 11.32 q 23(123,388-76,100,854) \times 3 \\
22 q 11.23(22,674,846-22,723,991) \times 0\end{array}$ \\
\hline 4 & NA & $\begin{array}{l}\text { LSI D13S319 42\% loss, } \\
\text { LSI } 13 q 34 \text { normal, LSI } \\
\text { ATM normal, CEP } 12 \\
\text { normal, LSI p53 normal }\end{array}$ & $13 q 14.13 q 14.3(45,945,097-50,339,992) \times 1$ & NA & NA \\
\hline 5 & NA & $\begin{array}{l}\text { LSI D13S319 normal, LSI } \\
\text { 13q34 normal, LSI ATM } \\
\text { normal, CEP } 1292 \% \\
\text { trisomy, LSI p53 normal }\end{array}$ & $12 p 13.33 q 24.33(60,861-132,267,241) \times 3$ & NA & NA \\
\hline 6 & NA & $\begin{array}{l}\text { LSI D13S319 97\% loss, } \\
\text { LSI 13q34 normal, LSI } \\
\text { ATM normal, CEP } 12 \\
74 \% \text { trisomy, LSI p53 } \\
\text { normal }\end{array}$ & $\begin{array}{l}12 \mathrm{p} 13.33 \mathrm{q} 24.33(60,861-132,267,241) \times 3 \\
13 q 14.3(49,074,574-50,628,718) \times 1\end{array}$ & NA & $19 p 13.3 q 13.43(220,598-63,782,017) \times 3$ \\
\hline 7 & NA & $\begin{array}{l}\text { LSI D13S319 91\% loss, } \\
\text { LSI 13q34 normal, LSI } \\
\text { ATM } 89 \% \text { loss, CEP } 12 \\
\text { normal, LSI p53 normal }\end{array}$ & $\begin{array}{l}11 q 13.4 q 24.3(72,459,008-130,030,128) \times 1, \\
13 q 14.11 q 21.1(43,421,790-53,019,141) \times 1\end{array}$ & NA & $2 \mathrm{p} 25.3 \mathrm{p} 11.2(44,198-89,912,901) \times 3$ \\
\hline 8 & NA & $\begin{array}{l}\text { LSI D13S319 normal, LSI } \\
13 q 34 \text { normal, LSI ATM } \\
\text { normal, CEP } 1263 \% \\
\text { trisomy, LSI p53 normal }\end{array}$ & $12 p 13.33 q 24.33(60,861-132,267,241) \times 3$ & NA & NA \\
\hline 9 & NA & $\begin{array}{l}\text { LSI D13S319 normal, LSI } \\
13 q 34 \text { normal, LSI ATM } \\
\text { normal, CEP } 1263 \% \\
\text { trisomy, LSI p53 normal }\end{array}$ & $12 p 13.33 q 24.33(60,861-132,267,241) \times 3$ & NA & NA \\
\hline 10 & NA & $\begin{array}{l}\text { LSI D13S319 92\% loss, } \\
\text { LSI } 13 \text { q34 } 12 \% \text { loss, LSI } \\
\text { ATM normal, CEP } 12 \\
\text { normal, LSI p53 normal }\end{array}$ & $13 q 14.3(49,407,720-50,523,594) \times 0 \sim 1$ & $\begin{array}{l}\text { Array did not detect } \\
13 q 34 \text { deletion seen } \\
\text { in } 12 \% \text { of cells by } \\
\text { FISH }\end{array}$ & $12 q 24.12(110,684,027-110,768,579) \times 3$ \\
\hline
\end{tabular}


Table 1 Thirty-four samples validated on an oligonucleotide array designed for detection of aberrations in leukemia and lymphoma* (Continued)

\begin{tabular}{|c|c|c|c|c|c|}
\hline 11 & NA & $\begin{array}{l}\text { LSI D13S319 normal, } \\
\text { LSI } 13 q 34 \text { normal, } \\
\text { LSI ATM normal, CEP } \\
12 \text { normal, LSI p53 } \\
\text { normal }\end{array}$ & NA & NA & 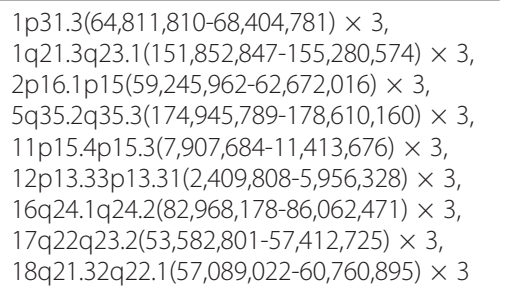 \\
\hline 12 & NA & $\begin{array}{l}\text { LSI D13S319 } 45 \% \\
\text { loss, LSI } 13 q 34 \\
\text { normal, LSI ATM } \\
47 \% \text {, CEP } 12 \text { normal, } \\
\text { LSI p53 normal }\end{array}$ & $\begin{array}{l}\text { 11q14.1q24.3(79,218,490-128,057,190) × } \\
\text { 13q14.11q21.33(43,525,071-71,879,067) × }\end{array}$ & NA & Yp11.31q12(2,706,656-57,735,230) × 0 \\
\hline 13 & NA & $\begin{array}{l}\text { LSI D13S319 93\% } \\
\text { loss, LSI } 13 q 34 \\
\text { normal, LSI ATM } \\
\text { normal, CEP } 12 \\
\text { normal, LSI p53 } \\
\text { normal }\end{array}$ & $13 q 14.3(49,457,877-50,339,992) \times 0$ & NA & NA \\
\hline 14 & NA & $\begin{array}{l}\text { LSI D13S319 normal, } \\
\text { LSI } 13934 \text { normal, } \\
\text { LSI ATM normal, CEP } \\
1271 \% \text { trisomy, LSI } \\
\text { p53 normal }\end{array}$ & 12p13.33q24.33(60,861-132,267,241) × 3 & NA & $\begin{array}{l}14 \mathrm{q} 24.1 \mathrm{q} 32.33(68,329,913-105,393,508) \times 1, \\
22 \mathrm{q} 11.23(22,674,846-22,723,991) \times 0\end{array}$ \\
\hline 15 & NA & $\begin{array}{l}\text { LSI D13S319 89\% } \\
\text { loss, LSI } 13 q 34 \\
\text { normal, LSI ATM 98\% } \\
\text { loss, CEP } 12 \text { normal, } \\
\text { LSI p53 normal }\end{array}$ & $\begin{array}{l}11 \mathrm{q} 14.3 \mathrm{q} 23.2(88,551,231-114,026,260) \times 1 \\
13 \mathrm{q} 14.2 \mathrm{q} 14.3(47,463,489-51,926,538) \times 1\end{array}$ & NA & $\begin{array}{l}2 \text { p16.1p14(56,499,065-66,570,230) × } \\
\text { 4p16.3p15.1 }(45,627-29,325,651) \times 1 \\
5 q 33.2 q 35.3(152,262,081-180,619,169) \times 3 \\
7 q 31.32 q 36.3(123,057,209-158,821,424) \times 3\end{array}$ \\
\hline 16 & NA & $\begin{array}{l}\text { LSI D13S319 40\% } \\
\text { loss, LSI } 13 q 34 \\
\text { normal, LSI ATM } \\
\text { normal, CEP } 12 \\
\text { normal, LSI p53 } \\
\text { normal }\end{array}$ & $13 q 14.2 q 14.3(47,691,117-50,339,992) \times 1$ & NA & $\begin{array}{l}1 \mathrm{q} 32.1(203,529,401-204,498,513) \times 1 \\
12 \mathrm{p} 13.33 q 24.33(60,861-132,267,241) \times 2 \sim 3\end{array}$ \\
\hline 17 & NA & $\begin{array}{l}\text { LSI D13S319 92\% } \\
\text { loss, LSI 13q34 } \\
\text { normal, LSI ATM 11\% } \\
\text { loss, CEP } 1290 \% \\
\text { trisomy, LSI p53 } \\
\text { normal }\end{array}$ & $\begin{array}{l}12 \mathrm{p} 13.33 \mathrm{q} 24.33(60,861-132,267,241) \times 3 \\
13 \mathrm{q} 13.3 \mathrm{q} 21.1(37,240,922-55,410,522) \times 1\end{array}$ & $\begin{array}{l}\text { Array did not detect } \\
\text { deletion of } 11 \text { q } 22.3 \\
\text { seen in } 11 \% \text { of cells } \\
\text { by FISH }\end{array}$ & 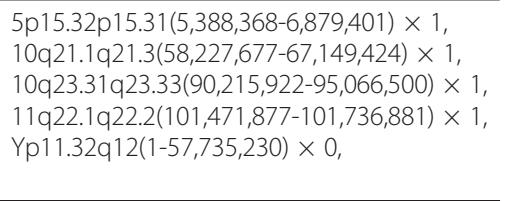 \\
\hline 18 & NA & $\begin{array}{l}\text { LSI D13S319 70\% } \\
\text { loss, LSI 13q34 } \\
\text { normal, LSI ATM 58\% } \\
\text { loss, CEP } 12 \text { normal, } \\
\text { LSI p53 normal }\end{array}$ & $\begin{array}{l}11 q 14.1 q 25(78,733,283-131,062,293) \times 1 \\
13 q 14.2 q 14.3(48,739,670-50,554,228) \times 1\end{array}$ & NA & NA \\
\hline
\end{tabular}


Table 1 Thirty-four samples validated on an oligonucleotide array designed for detection of aberrations in leukemia and lymphoma* (Continued)

\begin{tabular}{|c|c|c|c|c|c|}
\hline 19 & NA & $\begin{array}{l}\text { LSI D13S319 96\% } \\
\text { loss, LSI } 13 q 34 \\
\text { normal, LSI ATM 98\% } \\
\text { loss, CEP } 12 \text { normal, } \\
\text { LSI p53 normal }\end{array}$ & $\begin{array}{l}11 q 14.3 q 23.3(91,814,326-116,080,874) \times 1 \\
13 q 14.2 q 14.3(48,774,702-50,765,417) \times 1\end{array}$ & NA & $\begin{array}{l}2 p 25.3 p 14(44,198-66,539,084) \times 3, \\
2 p 14 p 11.2(66,729,955-88,771,193) \times 2 \sim 3, \\
4 q 32.3 q 35.2(166,094,098-191,152,793) \times 1, \\
6 q 16.3 q 27(102,816,244-170,736,131) \times 1 \sim 2, \\
7 p 22.1 p 11.2(6,480,544-55,435,373) \times 2 \sim 3, \\
8 q 23.1 q 24.3(107,914,570-146,263,042) \times 3, \\
11 p 15.1 p 14.3(21,533,469-22,367,835) \times 1, \\
11 p 14.3(22,398,459-24,320,961) \times 3,13 q 13.3 \\
(37,240,922-38,696,855) \times 1,13 q 14.11 q 14.12 \\
(43,995,777-5,551,120) \times 3,13 q 14.3 q 21.1 \\
(50,795,724-52,401,010) \times 3,13 q 21.1 q 21.2 \\
(55,083,523-58,084,123) \times 3,13 q 21.2 \\
(59,114,933-59,262,005) \times 3,13 q 21.31 q 21.32 \\
(63,478,713-65,130,349) \times 3,13 q 21.33 q 34 \\
(67,650,203-114,103,644) \times 3,19 p 13.3 \\
(220,598-546,817) \times 1,21 q 22.3(42,101,144- \\
46,915,771) \times 2 \sim 3\end{array}$ \\
\hline 20 & NA & $\begin{array}{l}\text { LSI D13S319 normal, } \\
\text { LSI } 13 q 34 \text { normal, } \\
\text { LSI ATM normal, CEP } \\
1266 \% \text { trisomy, LSI } \\
\text { p53 } 62 \% \text { loss }\end{array}$ & $\begin{array}{l}\text { 12p13.33q24.33(60,861-132,267,241) × } \\
\text { 17p13.3p11.1 }(49,128-22,116,415) \times 1\end{array}$ & NA & 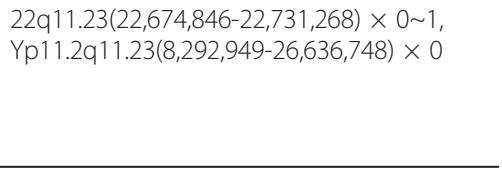 \\
\hline 21 & NA & $\begin{array}{l}\text { LSI D13S319 92\% } \\
\text { loss, LSI } 13 q 34 \\
\text { normal, LSI ATM } \\
\text { normal, CEP } 12 \\
\text { normal, LSI p53 } \\
\text { normal }\end{array}$ & $13 q 14.2 q 14.3(46,444,224-50,554,228) \times 1$ & NA & NA \\
\hline 22 & NA & $\begin{array}{l}\text { LSI D13S319 normal, } \\
\text { LSI } 13 q 34 \text { normal, } \\
\text { LSI ATM normal, CEP } \\
1235 \% \text { trisomy, LSI } \\
\text { p53 normal }\end{array}$ & 12 p13.33q24.33 $(60,861-132,267,241) \times 3$ & NA & NA \\
\hline 23 & NA & $\begin{array}{l}\text { LSI D13S319 29\% } \\
\text { loss, LSI } 13 q 34 \\
\text { normal, LSI ATM } \\
\text { normal, CEP } 12 \\
\text { normal, LSI p53 } \\
\text { normal }\end{array}$ & $13 q 14.3(49,604,393-49,730,034) \times 1$ & NA & NA \\
\hline 24 & NA & $\begin{array}{l}\text { LSI D13S319 88\% } \\
\text { loss, LSI 13q34 } \\
\text { normal, LSI ATM } \\
\text { normal, CEP } 12 \\
\text { normal, LSI p53 } \\
\text { normal }\end{array}$ & $13 q 14.2 q 14.3(46,444,224-50,554,228) \times 1$ & NA & NA \\
\hline
\end{tabular}


Table 1 Thirty-four samples validated on an oligonucleotide array designed for detection of aberrations in leukemia and lymphoma* (Continued)

\begin{tabular}{|c|c|c|c|c|c|}
\hline 25 & $\begin{array}{l}\text { 44 46,X,X,add(1)(p36.1),i(6) } \\
\text { (p10),del(8)(p21 p23),add } \\
\text { (12)(p11.2),-13, del(14) } \\
\text { (q12q32),-15, add(17) } \\
\text { (p11.2),+2-6mar[cp11]/46, } \\
\text { XX[9] }\end{array}$ & $\begin{array}{l}\text { LSI D13S319 34\% } \\
\text { loss, LSI p53 49\% } \\
\text { loss }\end{array}$ & $\begin{array}{l}13 q 14.2 q 14.3(47,524,866-50,523,594) \times 1 \\
17 p 13.3 p 13.1(49,128-8,581,862) \times 1\end{array}$ & $\begin{array}{l}\text { Array did not detect } \\
\text { del(14)(q12q32) seen } \\
\text { on karyotype; - } 15 \\
\text { shows complexity on } \\
\text { array }\end{array}$ & 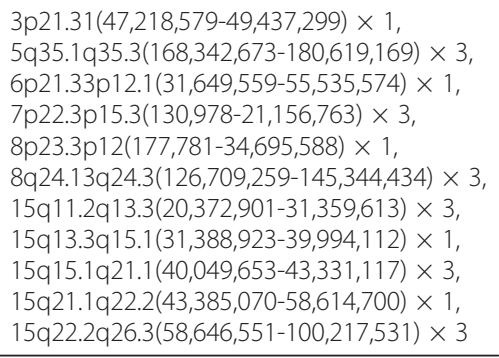 \\
\hline 26 & $47, X Y,+12[\mathrm{cp} 7] / 46, X Y[13]$ & $\begin{array}{l}\text { LSI D13S319 normal, } \\
\text { LSI } 13 q 34 \text { normal, } \\
\text { LSI ATM normal, CEP } \\
1277.5 \% \text { trisomy, LSI } \\
\text { p53 normal }\end{array}$ & 12p13.33q24.33(60,861-132,267,241) × 3 & NA & $\begin{array}{l}7 \mathrm{q} 34(141,693,456-141,719,136) \times 1,14 \mathrm{q} 22.2 \\
(53,498,118-53,858,816) \times 3\end{array}$ \\
\hline 27 & $\begin{array}{l}\text { 46,XY,del(11)(q13q23)[5]/ } \\
47, \text { idem,+12[8]/46,XY[7] }\end{array}$ & $\begin{array}{l}\text { LSI D13S319 67\% } \\
\text { loss, LSI ATM 93\% } \\
\text { loss, CEP } 1215 \% \\
\text { trisomy }\end{array}$ & $\begin{array}{l}11 \mathrm{q} 13.5 \mathrm{q} 23.3(76,383,882-117,091,784) \times 1, \\
12 \mathrm{p} 13.33 \mathrm{q} 24.33(1-132,349,534) \times 3 \\
13 q 14.2 q 14.3(47,172,707-50,586,402) \times 1 \sim 2\end{array}$ & NA & NA \\
\hline 28 & $47, X Y,+12[6] / 46, X Y[14]$ & $\begin{array}{l}\text { LSI D13S319 normal, } \\
\text { LSI } 13934 \text { normal, } \\
\text { LSI ATM normal, CEP } \\
1261 \% \text { trisomy, LSI } \\
\text { p53 normal }\end{array}$ & 12p13.33q24.33(60,861-132,267,241) × 3 & NA & NA \\
\hline 29 & $\begin{array}{l}45, X Y, \text { del(13)(q21q34),-17 } \\
{[3] / 46, X Y, \operatorname{del}(17)(\mathrm{p} 11.2)[3] /} \\
46, \mathrm{XY}[14]\end{array}$ & $\begin{array}{l}\text { LSI D13S319 normal, } \\
\text { LSI ATM normal, CEP } \\
12 \text { normal, LSI p53 } \\
45 \% \text { loss }\end{array}$ & 17p13.3p11.2(49,128-21,376,245) × 1 & $\begin{array}{l}\text { Array and FISH did } \\
\text { not detect del(13) } \\
\text { (q21q34) seen in } 3 / 20 \\
\text { cells by karyotype }\end{array}$ & NA \\
\hline 30 & $\begin{array}{l}47, X Y,+12[4] / 47, \text { idem,del } \\
(11)(q 13 q 23)[4] / 46, X Y[8]\end{array}$ & $\begin{array}{l}\text { LSI D13S319 normal, } \\
\text { LSI } 13 \text { q34 normal, } \\
\text { LSI ATM } 10.5 \% \text { loss, } \\
\text { CEP } 1285 \% \text { trisomy, } \\
\text { LSI p53 normal }\end{array}$ & 12p13.33q24.33(60,861-132,267,241) × 3 & $\begin{array}{l}\text { Array did not detect } \\
11 \text { q } 22.3 \text { deletion seen } \\
\text { in } 10.5 \% \text { of cells by } \\
\text { FISH and in } 4 / 16 \text { cells } \\
\text { by karyotype }\end{array}$ & $\begin{array}{l}13 q 12.2(27,492,830-27,493,700) \times 3 \\
22 q 11.23(22,674,846-22,731,268) \times 0\end{array}$ \\
\hline 31 & $\begin{array}{l}\text { 44 46,XY, del(6)(q15q23)[6]/ } \\
\text { 42 44, idem,-3,-4,add(4) } \\
\text { (p14),-8,add(10)(q22),del } \\
\text { (13)(q12q22),add(17)(p11.2) } \\
\text { [cp14] }\end{array}$ & NA & 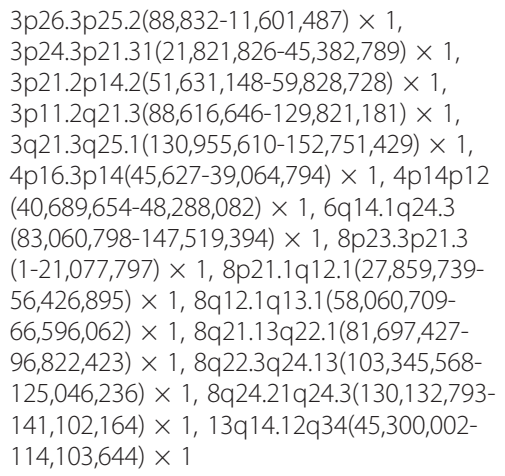 & NA & 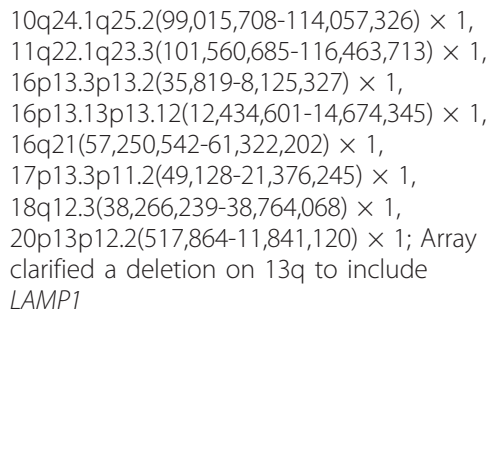 \\
\hline
\end{tabular}


Table 1 Thirty-four samples validated on an oligonucleotide array designed for detection of aberrations in leukemia and lymphoma* (Continued)

\begin{tabular}{|c|c|c|c|c|c|}
\hline 32 & $\begin{array}{l}45 \sim 46, X X, \text { del }(17) \\
(\text { p11.2p13),-20, +mar } \\
{[c p 16] / 45 \sim 46, \text { idem,add(3) }} \\
(q 25)[3] / 46, X Y[3]\end{array}$ & $\begin{array}{l}\text { LSI D13S319 72\% } \\
\text { loss, LSI 13q34 } \\
\text { normal, LSI ATM } \\
\text { normal, CEP } 12 \\
\text { normal, LSI p53 } \\
79.5 \% \text { loss }\end{array}$ & 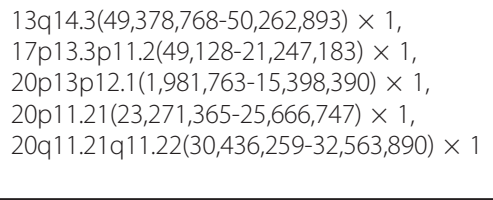 & NA & $\begin{array}{l}3 p 21.31(46,911,912-49,973,212) \times 1 \\
17 q 21.1 q 21.31(35,551,063-37,865,072) \times 1\end{array}$ \\
\hline 33 & $\begin{array}{l}45, \mathrm{XY},-4, \operatorname{add}(17)(\mathrm{p} 13)[1] / \\
44, \mathrm{idem}, \mathrm{add}(13)(\mathrm{p} 12), \mathrm{add} \\
(14)(\mathrm{q} 32),-15, \mathrm{del}(20) \\
(\mathrm{q} 11.2 \mathrm{q} 13.3)[16] / 46, \mathrm{XY}[3]\end{array}$ & NA & $\begin{array}{l}4 p 16.3 p 14(45,627-38,504,396) \times 1, \\
4 p 13 q 22.3(41,631,408-96,524,997) \times 1 \\
15 q 11.2 q 15.1(19,129,891-38,918,282) \times 1 \\
15 q 21.2 q 22.2(49,131,112-57,212,181) \times 1\end{array}$ & $\begin{array}{l}\text { del(20)(q11.2q13.3) } \\
\text { not detected by } \\
\text { aCGH }\end{array}$ & $\begin{array}{l}11 \mathrm{q} 22.3 \mathrm{q} 23.2(106,821,962-113,825,965) \times 1, \\
13 \mathrm{q} 12.11(19,508,097-20,625,750) \times 1, \\
17 \mathrm{p} 13.3(49,128-2,779,693) \times 1,17 \mathrm{p} 13.1 \mathrm{p} 11.2 \\
(9,888,292-18,868,118) \times 1,17 \mathrm{p} 11.2 \\
(19,082,873-20,794,597) \times 1,22 \mathrm{q} 11.23 \\
(22,674,846-22,723,991) \times 0\end{array}$ \\
\hline 34 & $\begin{array}{l}45, X,-Y[7] / 46, X Y, \operatorname{add}(8) \\
(\mathrm{p} 11.2), \operatorname{add}(11)(\mathrm{q} 13)[4] / 46 \\
\text { XY[9] }\end{array}$ & $\begin{array}{l}\text { LSI D13S319 62.5\% } \\
\text { loss, LSI } 13 q 34 \\
\text { normal, LSI ATM 31\% } \\
\text { loss, CEP } 12 \text { normal, } \\
\text { LSI p53 normal }\end{array}$ & $\begin{array}{l}11 q 13.4 q 25(72,590,406-134,425,038) \times 1 \\
13 q 14.2 q 14.3(47,588,669-50,414,293) \times 1\end{array}$ & $\begin{array}{l}-Y \text { not detected by } \\
\text { aCGH }\end{array}$ & $\begin{array}{l}\text { 7p22.3p12.2(130,978-49,815,456) × } \\
8 p 23.3 p 12(1-33,376,370) \times 1,22 q 12.2 q 13.33 \\
(30,406,286-49,519,766) \times 3\end{array}$ \\
\hline
\end{tabular}

aCGH, array-based comparative genomic hybridization; NA, not applicable

*Rearrangements at the immunoglobulin loci were excluded except for $\alpha$ T-cell receptor loci (13q14.2) and $\beta$ T-cell receptor loci (7q34) since they can recombine in malignant B cells [19]. 


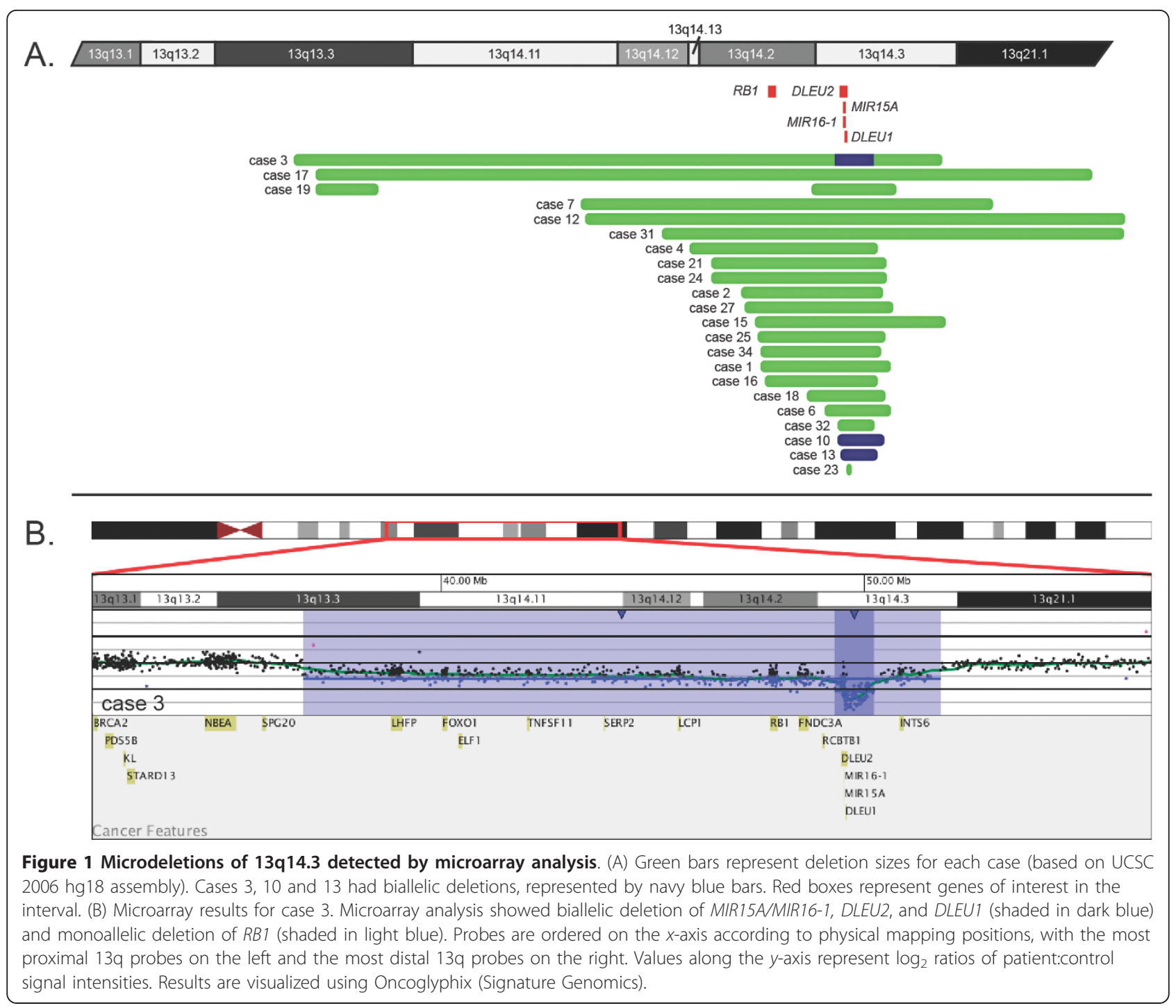

a better predictor of overall survival than what can be understood based on FISH. For example, it has been suggested that genomic variation may offer insight into the potential aggressive behaviors for the disease [12]. Larger deletions that include the $R B 1$ locus have been proposed to be associated with greater genomic complexity and a more aggressive course. However, in the current study, several cases (e.g., cases 19 and 32) had 13q14 deletions that did not encompass $R B 1$ and still presented with complex findings, and other cases had deletions that encompassed $R B 1$ but lacked significant complexity. Further studies are warranted to determine the prognostic value of sizing $13 q$ deletions.

All trisomy 12-positive cases were detected by microarray analysis. The percentage of abnormal cells detected ranged from $15 \%$ to $92 \%$ (as determined by FISH). Trisomy 12 was identified by microarray analysis in one additional case in which FISH analysis was normal (case 16); follow-up studies on this case were not possible.

Nine cases had known deletions of $11 \mathrm{q} 22.3 /$ ATM as determined by FISH and/or karyotype. Eight of these were identified by aCGH. The deletions ranged in size from $0.27 \mathrm{Mb}$ to $61.8 \mathrm{Mb}$. In case 17 with an $11 \mathrm{q} 22.3$ deletion not detected by aCGH, the deletion was present in $11 \%$ of the interphase cells scored by FISH. Deletions of $11 \mathrm{q}$ that include $A T M$ were found by aCGH in two cases that were missed by karyotype: case 31 had a 14.9$\mathrm{Mb}$ deletion at 11q22.1q23.3, and case 33 had a $7-\mathrm{Mb}$ deletion at $11 \mathrm{q} 22.3 \mathrm{q} 23.2$. FISH was not performed in either case.

These cases with commonly found abnormalities illustrate the ability and limitations of aCGH to detect a relatively low number of cells with the abnormal clone ( $\sim 15 \%)$ and to detect aberrations missed by conventional chromosome analysis and FISH. The high-density 
coverage afforded by the array design used in the current study likely contributes to both improved sensitivity in detecting known lower-level mosaic alterations and an improved ability to recognize new alterations. However, lower-level limits of resolution do persist for aCGH due to the nature of the technology. Thus, even with the improvements described herein, this assay should be used only for new diagnoses or relapse and not for monitoring for minimal residual disease.

\section{Microarray analysis can clarify the karyotypes}

Karyotype complexity can be delineated by aCGH. For example, case 25 had a reported karyotype of monosomy 15 with two to six markers. Microarray analysis identified a series of gains and losses that included $15 \mathrm{q} 11.2 \mathrm{q} 13.3 \times 3,15 \mathrm{q} 13.3 \mathrm{q} 15.1 \times 1,15 \mathrm{q} 15.1 \mathrm{q} 21.1 \times 3$, $15 \mathrm{q} 21.1 \mathrm{q} 22.2 \times 1$, and $15 \mathrm{q} 22.2 \mathrm{q} 26.3 \times 3$. This result may represent the markers seen by karyotyping, although FISH was not performed to confirm these findings. For some cases in which karyotyping was not performed, we found highly complex genomic changes (e.g., cases 11 and 19).

In several cases, karyotyping showed abnormalities that should have been detected by microarray analysis but were not (Table 1). For example in case 29, karyotyping showed deletion of 13q that was not detected by array or locus-specific FISH, and in case 33 karyotyping showed a deletion at $20 \mathrm{q} 11.2 \mathrm{q} 13.3$ in 16 of 20 cells that was not identified by microarray analysis. These results may indicate that the karyotype was not interpreted correctly and that no deletions are present at these loci.

Finally, aCGH clarified the deletion/rearrangement of 17 p13.1 identified by prior karyotyping in two cases (cases 31 and 33). In both cases, microarray analysis identified a deletion of $17 \mathrm{p}$. In case 31 , the deletion encompasses TP53 that by karyotyping had been interpreted as an add(17p). Case 33 also had an add(17p) by karyotype analysis. Array analysis showed a deletion of $17 \mathrm{p}$, but the deletion does not include TP53. Deletion of $17 \mathrm{p}$ is considered an independent prognostic factor with resistance to treatment, shorter treatment-free interval, and shorter overall survival [17]. Thus, aCGH can clarify the chromosome results, and in some cases, the identification of a deletion involving TP53 would change the prognosis for the patient and may be used to alter treatment or patient management. Additional cases in which the array results changed the prognosis are discussed in the following section.

\section{New prognostic information obtained by microarray analysis}

In addition to common aberrations, we identified clinically significant or potentially significant gains or losses that were not known prior to submitting the sample for array analysis in the majority of cases (20/34), including trisomy 18 and 19 and deletions of 6q, which are highlighted here.

Trisomy 18 and trisomy 19, each seen in separate cases in our study, are uncommon in CLL. Trisomy 18 generally presents as the sole abnormality or with a karyotype that includes trisomy 12 or trisomy 19 [18]. Trisomy 19 in addition to trisomy 12 has been associated with IGHV gene mutation [13]. In that study of 705 cases of CLL, trisomy 19 was seen in 11 (1.6\%) cases, all of which also had trisomy 12; nine had mutated IGHV genes. Those cases that did not have trisomy 19 but had trisomy 12 primarily had unmutated IGHV genes [13]. In our study, trisomy 12 was seen with trisomy 19 in case 6, although the $I G H V$ mutational status is not known. In case 3 with trisomy 18 , neither trisomy 12 nor 19 was detected.

Large ( $64 \mathrm{Mb})$ deletions of $6 \mathrm{q}$ were detected in two cases, one of which, case 19, was not known prior to array analysis presumably because chromosome analysis was not performed. Cases of CLL with deletions of $6 \mathrm{q}$ are characterized by atypical lymphocyte morphology, CD38 positivity, and intermediate incidence of $\operatorname{IgVH}$ somatic hypermutation [14]. Cases of CLL with deletion of $6 \mathrm{q}$ (specifically at $6 \mathrm{q} 21$ ) are seen in less than $5 \%$ of CLL cases, have been shown to require a more demanding treatment regimen, and have been suggested to comprise an intermediate-risk group [14,15]. Deletion of $6 \mathrm{q}$ with or without other abnormalities may also be predictive of shorter survival [15].

In four cases (cases 7, 11, 15 and 19) for which only limited FISH was performed prior to aCGH analysis, new information was revealed and showed gains of $2 \mathrm{p}$, which encompassed $2 \mathrm{p} 16.1 \mathrm{p} 15$, ranging in size from 3.4 $\mathrm{Mb}$ to $89.8 \mathrm{Mb}$ that included the REL and BCL11A genes. Gains in the $2 \mathrm{p} 16.1 \mathrm{p} 15$ region have been associated with a poor prognosis and have been seen more frequently in cases that have deletion $17 p-$ [16], although we did not see this association. The ability to perform microarray analysis on residual or archived material provides an opportunity to analyze the cancer genome in an unbiased and comprehensive approach.

\section{Novel aberrations identified by microarray analysis}

We found 10 novel changes by microarray analysis that were not identified by karyotype or FISH and that may have clinical significance. For example in case 17, microarray detected additional losses, including a $265-\mathrm{kb}$ loss on 11q that included BIRC3. This gene is part of the inhibitor of apoptosis (IAP) family, which plays a role in apoptosis and the inflammatory process [24] and, when fused by translocation to MALT1, is associated with MALT-type lymphoma [25]. Interestingly, we have identified a novel translocation of BIRC3 to SETBP1 in a 
separate case of CLL (unpublished observation). Furthermore, an NF-kB inhibitor has recently been shown to achieve apoptosis induction with potential therapeutic value for CLL in cases with reduced expression of BIRC3 [26]. This suggests that BIRC3 status may be an important factor in determining appropriate therapy and prognosis. However, further investigations are warranted. A recent publication reported atypical deletions of $11 \mathrm{q}$ in patients with CLL [27]. However, their minimal deletion region, as established by BAC array analysis, did not include $B I R C 3$, as found in case 17 in our study.

In six cases (cases 1, 3, 14, 20, 30 and 33), a biallelic deletion at 22q11.23 of 49 to $56 \mathrm{~kb}$ that includes GSTT1 was found by array only (Figure 2). GSTT1, along with GSTM1 and GSTP1, is part of the glutathione S-transferase family, which encodes for enzymes that catalyze the conjugation of reduced glutathione to a variety of electrophilic and hydrophobic compounds. The enzyme activity of GSTT1 towards methyl chloride in erythrocytes can be measured and placed into three groups: nonconjugators, low conjugators, and high conjugators. Nonconjugators are assumed to have the GSTT1-null genotype and have been noted to have increased genotoxic affects such as sister chromatid exchanges after exposure to toxic agents such as methyl bromide [28]. Individuals with the GSTT1-null genotype have been shown to be at a increased risk for developing MDS [22], and polymorphisms in GSTM1 and GSTP are associated with a higher risk of developing CLL [29]. Based on BAC-array analysis, Gunn and coworkers [30] identified deletions of 22q11.22 involving the genes GGTLC2 and PRAME. This region is proximal to and appears non-overlapping with the novel deletions reported here of GSTT1 in 22q11.23.

Additional, novel aberrations included case 11 that had a $3.6-\mathrm{Mb}$ gain that encompassed $5 \mathrm{q} 35.2 \mathrm{q} 35.3$ and included CDHR2 (Figure 3A), a tumor suppressor

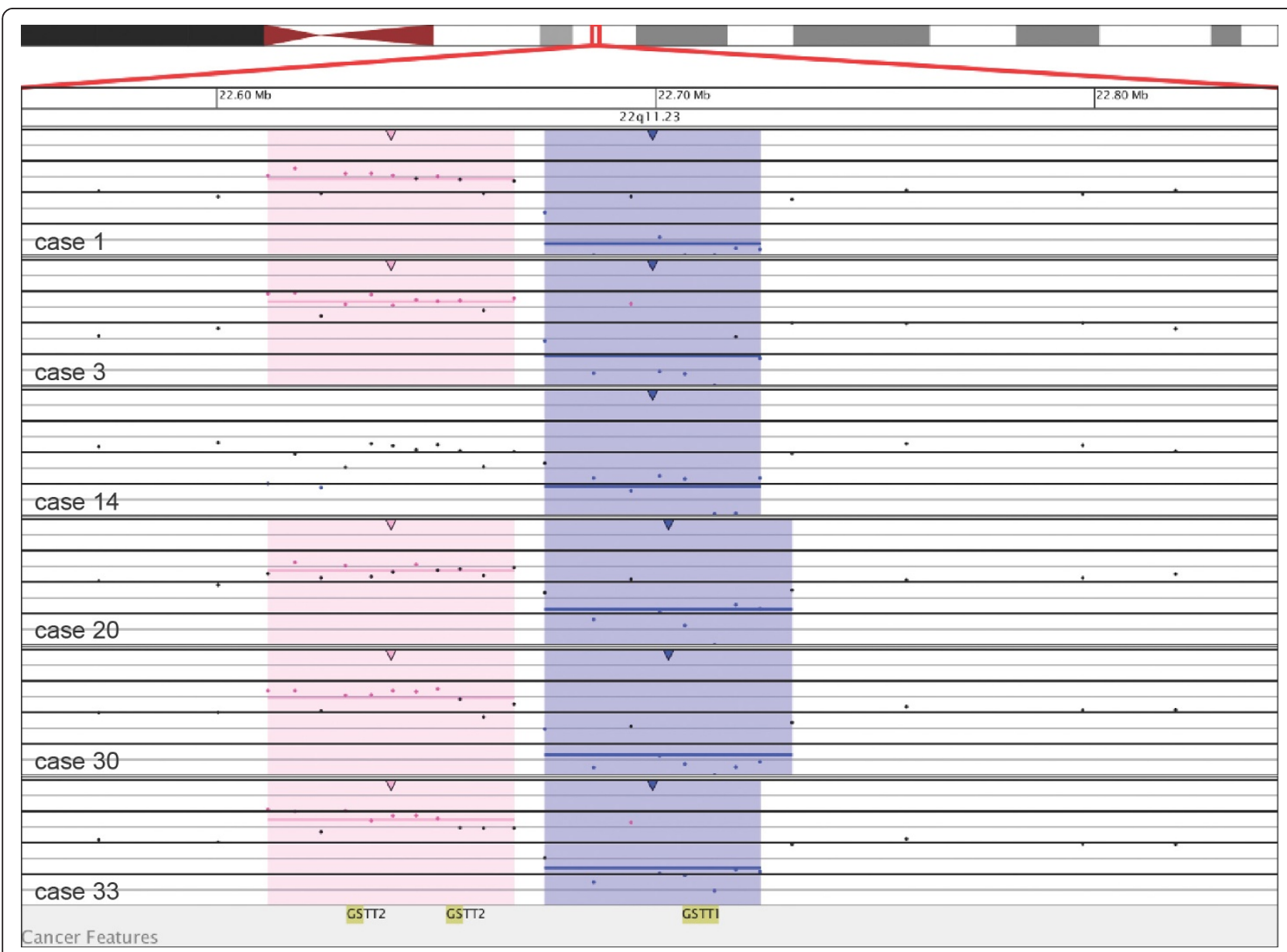

Figure 2 Microarray results for six cases (cases 1, 3, 14, 20, 30 and 33) with a biallelic deletion at $22 q 11.23$ of 49 to $56 \mathrm{~kb}$ that includes GSTT1. Probes are ordered on the $x$-axis according to physical mapping positions, with the most proximal 22q probes on the left and the most distal 22q probes on the right. Values along the $y$-axis represent $\log _{2}$ ratios of patient:control signal intensities. Results are visualized using Oncoglyphix (Signature Genomics). 

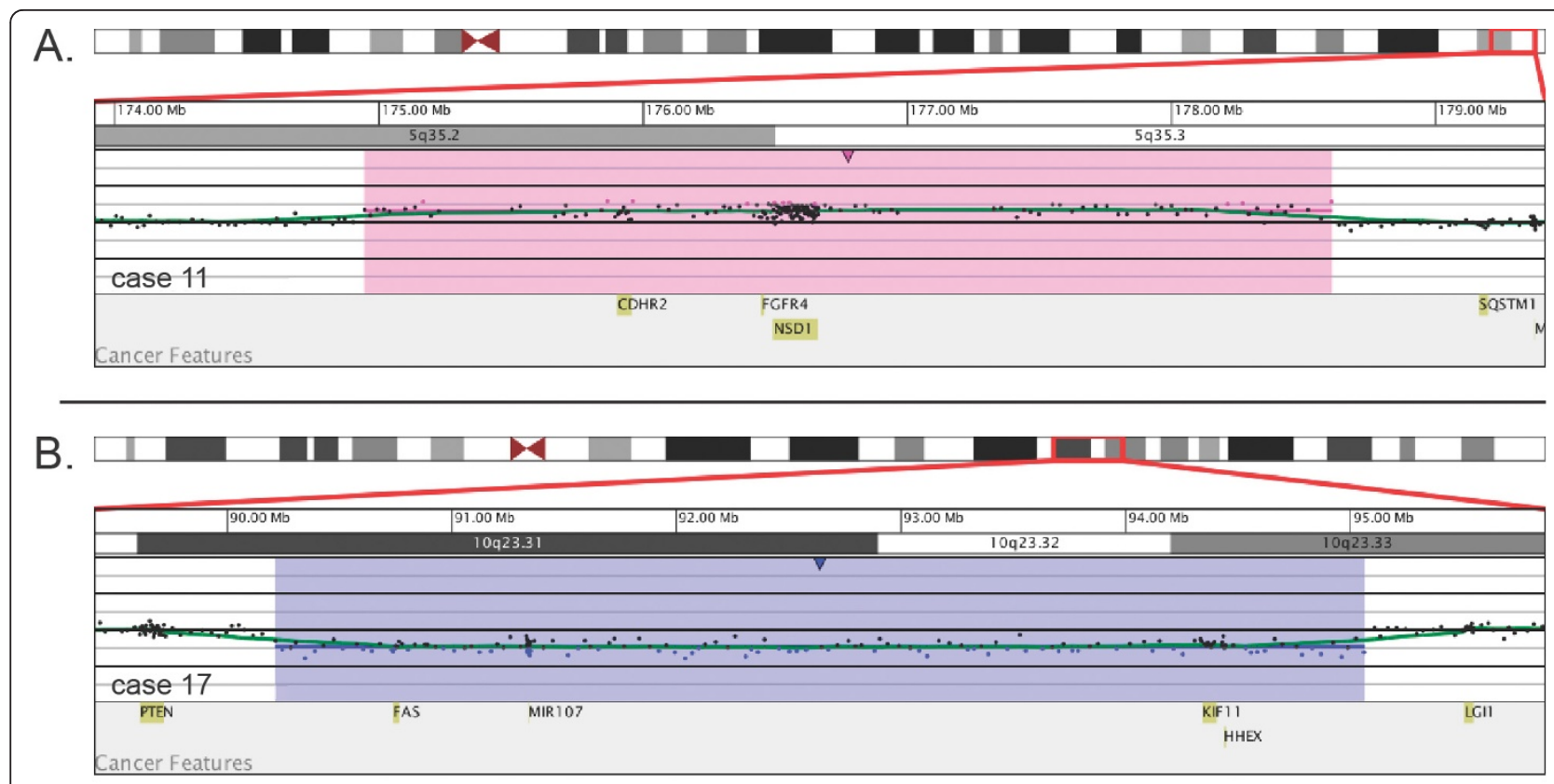

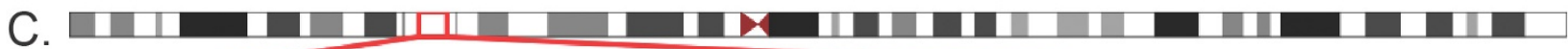

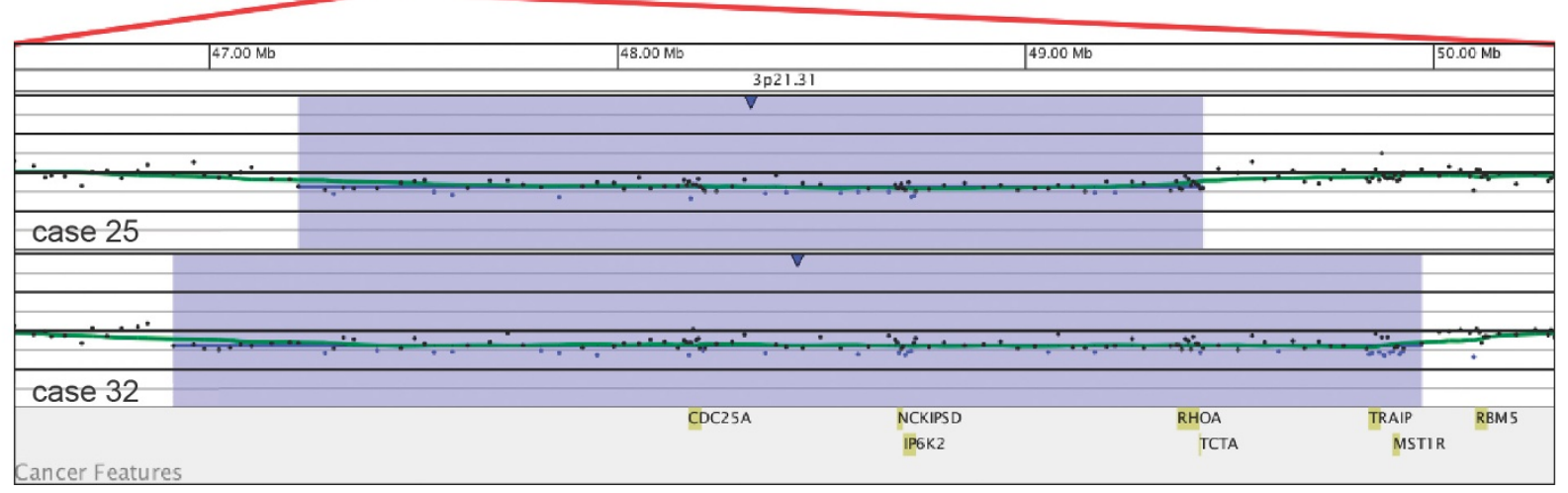

Figure 3 Novel aberrations by microarray. (A) Microarray results for case 11 showing a 3.6-Mb gain (shaded in pink) encompassing 5 q35.2q35.3 that includes CDHR2, a tumor suppressor candidate. Probes are ordered on the $x$-axis according to physical mapping positions, with the most proximal $5 \mathrm{q}$ probes on the left and the most distal $5 \mathrm{q}$ probes on the right. (B) Microarray results for case 17 showing a 4.8-Mb deletion (shaded in blue) at 10q23.31q23.33 that includes MIR107 and FAS. Probes are ordered on the $x$-axis according to physical mapping positions, with the most proximal 10q probes on the left and the most distal 10q probes on the right. (C) Microarray results for cases 25 and 32 with deletions (shaded in blue) of 3p21.31 that include CDC25A. Case 25 has a 2.2-Mb deletion, and case 32 has a 3.1-Mb deletion. CDC25A is required for progression from G1 to $S$ phase in the cell cycle. Probes are ordered on the $x$-axis according to physical mapping positions, with the most distal $3 p$ probes on the left and the most proximal $3 p$ probes on the right. For $A-C$, values along the $y$-axis represent $\log _{2}$ ratios of patient:control signal intensities. Results are visualized using Oncoglyphix (Signature Genomics).

candidate [31]. In case 17 , a $4.8-\mathrm{Mb}$ deletion at 10q23.31q23.33 was identified that includes MIR107 and FAS (Figure 3B). MIR107 plays a role in inhibiting differentiation in granulocytic, monocytic, and B-lymphoid lines [32], whereas $F A S$ is involved with apoptosis, and mutations in $F A S$ are known to cause autoimmune lymphoproliferative syndrome [33]. Cases 25 and 32 had a deletion at 3p21.31 of $2.2 \mathrm{Mb}$ and $3.06 \mathrm{Mb}$, respectively, that included $C D C 25 A$ (Figure $3 C$ ), which is required for progression from $\mathrm{G} 1$ to $\mathrm{S}$ phase in the cell cycle
[34]. Both cases 25 and 32 exhibit deletions of MIR15A/ MIR16-1 and TP53, but not ATM. This may prove to be related to the acquisition and/or significance of the $C D C 25 A$ deletion. Identification of additional cases with deletions of these novel genes may assist in understanding their potential roles in CLL.

\section{Conclusions}

We have used a novel approach of targeting over 1800 cancer feature genes while also providing whole genome 
coverage to identify novel changes and delineate breakpoints of alterations. Using this approach, we have shown that such an array design in CLL will identify cryptic and novel alterations, clarify the karyotype results and refine breakpoints, which may lead to better prognostic precision in CLL, and may influence treatment or patient management. This approach is likely superior to using small, targeted arrays that may miss important novel changes or high-density, whole-genome arrays that have arbitrary coverage and may yield findings that are difficult to interpret in the context of the patient's disease. Arrays also may be useful for cases in which the chromosome analysis and FISH results are discordant with each other, with the pathology, or with disease course. Because the array uses DNA extracted directly from the specimen, aCGH may be useful for cases of tissue culture failure. Finally, microarrays may be helpful when cytogenetics is negative or ambiguous. Because CLL rarely involves balanced translocations, which are not detectable by aCGH, this technology may be particularly useful for these patients, especially in understanding the cancer genomes for the $10-20 \%$ of cases representing young patients [35], who exhibit a significantly reduced life expectancy relative to healthy controls once symptomatic with this disease [36].

\section{Materials and methods DNA extraction}

DNA was extracted from 34 samples collected from patients with either newly diagnosed CLL or recurrent disease. All samples were karyotypically abnormal by conventional cytogenetics, FISH, or both. The samples consisted of 22 peripheral bloods, 11 bone marrow aspirates, and one lymph node. The specimens were deidentified for demographic details but retained data regarding prior chromosome and FISH analyses. The protocol of testing of de-identified, discarded specimens was approved by the Institutional Review Board (IRB) Spokane, and IRB approval was obtained by the source laboratories where required by local regulations.

Genomic DNA was extracted from unenriched blood and bone marrow specimens using the Gentra Puregene Blood kit (Qiagen, Germantown, MD) according to the manufacturer's instructions. Two million cells or $150 \mu \mathrm{l}$ (if cell counts were unavailable) of blood or bone marrow were used as starting material. Additional cell lysis solution (Gentra Puregene Blood kit) was added to samples with high viscosity to ensure complete cell lysis. Samples were stabilized in cell lysis solution within 2448 hours when possible to ensure high-quality DNA for use on the microarray.

DNA quality was assessed by measuring DNA concentration, $260 / 280$ and 260/230 readings on a Nanodrop 2000 Spectrophotometer (Thermo Scientific, Waltham,
MA). The DNA was also run on a $1 \%$ agarose gel with ethidium bromide to determine if degradation was present. To be included in the study, samples had to have minimal degradation with 260/280 values near 1.8 and 260/230 readings greater than 1.35 .

\section{Oligonucleotide microarray labeling, hybridization, and analysis}

Oligonucleotide-based microarray analysis was performed using a $135 \mathrm{~K}$-feature whole-genome microarray (Signature OncoChip ${ }^{\mathrm{TM}}$, designed by Signature Genomic Laboratories, Spokane, WA; manufactured by Roche NimbleGen, Madison, WI). This microarray targets 1893 cancer features, including genes with known roles in hematologic malignancies or solid tumors in which deletions or mutations had been previously reported; genes with suspected roles in cancer based on prior expression studies without specific evidence of genomic copy changes; genes with previously speculated roles based solely upon association with a biological pathway or gene family; and genes involved in protein and miRNA coding. The microarray has an average oligonucleotide coverage of one oligo per $0.2-7 \mathrm{~kb}$ for targeted cancer features with additional genomic backbone coverage of approximately one oligo per $35 \mathrm{~kb}$. Purified genomic DNA from the diagnostic specimens was labeled with Cyanine dye Cy5, and DNA from a chromosomally normal control was labeled with Cyanine dye Cy3, using a Roche NimbleGen Dual-Color DNA Labeling Kit according to the manufacturer's instructions. Array hybridization and washing were performed as specified by the manufacturer (Roche NimbleGen). Arrays were scanned at 5 microns using an MS 200 Microarray Scanner (Roche NimbleGen) and analyzed using MS 200 1.0 Scanning Software (Roche NimbleGen), NG Packager 1.0 (Signature Genomics) and NimbleScan 2.6 (Roche NimbleGen). Results were then displayed using custom oligonucleotide aCGH analysis software (Oncoglyphix ${ }^{\mathrm{TM}}$, Signature Genomics).

\section{Acknowledgements \\ We thank Erin Dodge (Signature Genomic Laboratories) for her critical editing and preparation of the manuscript. \\ Author details \\ ${ }^{1}$ Sacred Heart Medical Center, 101 West 8th Avenue, Spokane, WA, 99204, USA. ${ }^{2}$ Signature Genomic Laboratories, PerkinElmer Inc., 2820 North Astor Street, Spokane, WA, 99207, USA. ${ }^{3}$ CSI Laboratories, 11525 Park Woods Circle, Alpharetta, GA, 30005, USA. ${ }^{4}$ Cleveland Clinic, Pathology \& Laboratory Medicine Institute, 9500 Euclid Avenue, Cleveland, OH, 44195, USA. ${ }^{5}$ Quest Diagnostics Nichols Institute, 14225 Newbrook Drive, Chantilly, VA, 20151, USA. ${ }^{6}$ Quest Diagnostics Nichols Institute, 33608 Ortega Highway, San Juan Capistrano, CA, 92675, USA.}

\section{Authors' contributions}

KAK, LGS, and AT wrote the manuscript; KAK, RAS, MLS, BCB, and LGS analyzed and interpreted the data; LGS, BCB, MLS, RAS, and TS designed the 
research; TCB, RRT, JRC, and KST contributed study samples; VC, CV, SM, NJN, SB, and SAM performed the research; LDM contributed to the discussion of research and data; and all authors critically reviewed and gave final approval of the manuscript.

\section{Competing interests}

RAS, LDM, VC, CV, SM, NJN, SB, SAM, BCB, and LGS are employees of Signature Genomic Laboratories, PerkinElmer, Inc. TS and MLS are employees of Quest Diagnostics. TCB is an employee of CSI Laboratories. The remaining authors have no conflict of interest to report.

Received: 26 August 2011 Accepted: 16 November 2011

Published: 16 November 2011

\section{References}

1. Patel A, Kang SH, Lennon PA, Li YF, Rao PN, Abruzzo L, Shaw C, Chinault AC, Cheung SW: Validation of a targeted DNA microarray for the clinical evaluation of recurrent abnormalities in chronic lymphocytic leukemia. Am J Hematol 2008, 83(7):540-546.

2. Higgins RA, Gunn SR, Robetorye RS: Clinical application of array-based comparative genomic hybridization for the identification of prognostically important genetic alterations in chronic lymphocytic leukemia. Mol Diagn Ther 2008, 12(5):271-280.

3. Rai KR, Sawitsky A, Cronkite EP, Chanana AD, Levy RN, Pasternack BS: Clinical staging of chronic lymphocytic leukemia. Blood 1975, 46(2):219-234.

4. Rai KR: A critical analysis of staging in CLL. In Chronic lymphocytic leukemia: recent progress, future direction. Edited by: Gale RP, Rai KR. New York: Alan R. Liss; 1987:253.

5. Binet JL, Auquier A, Dighiero G, Chastang C, Piguet H, Goasguen J, Vaugier G, Potron G, Colona P, Oberling F, Thomas M, Tchernia G, Jacquillat C, Boivin P, Lesty C, Duault MT, Monconduit M, Belabbes $S$, Gremy F: A new prognostic classification of chronic lymphocytic leukemia derived from a multivariate survival analysis. Cancer 1981, 48(1):198-206.

6. Damle RN, Wasil T, Fais F, Ghiotto F, Valetto A, Allen SL, Buchbinder A, Budman D, Dittmar K, Kolitz J, Lichtman SM, Schulman P, Vinciguerra VP, Rai KR, Ferrarini M, Chiorazzi N: Ig V gene mutation status and CD38 expression as novel prognostic indicators in chronic lymphocytic leukemia. Blood 1999, 94(6):1840-1847.

7. Hamblin TJ, Davis Z, Gardiner A, Oscier DG, Stevenson FK: Unmutated Ig V (H) genes are associated with a more aggressive form of chronic lymphocytic leukemia. Blood 1999, 94(6):1848-1854.

8. Shanafelt TD: Predicting clinical outcome in CLL: how and why. Hematology Am Soc Hematol Educ Program 2009, 421-429.

9. Maciejewski JP, Mufti GJ: Whole genome scanning as a cytogenetic tool in hematologic malignancies. Blood 2008, 112(4):965-974.

10. Lichter P: All you need is a Mir-acle: the role of nontranslated RNAs in the suppression of B cell chronic lymphocytic leukemia. Cancer Cell 2010, 17(1):3-4.

11. Klein U, Lia M, Crespo M, Siegel R, Shen Q, Mo T, Ambesi-Impiombato A, Califano A, Migliazza A, Bhagat G, Dalla-Favera R: The DLEU2/miR-15a/16-1 cluster controls $B$ cell proliferation and its deletion leads to chronic lymphocytic leukemia. Cancer Cell 2010, 17(1):28-40.

12. Parker H, Rose-Zerilli MJ, Parker A, Chaplin T, Wade R, Gardiner A, Griffiths M, Collins A, Young BD, Oscier DG, Strefford JC: 13q deletion anatomy and disease progression in patients with chronic lymphocytic leukemia. Leukemia 2011, 25(3):489-497.

13. Sellmann L, Gesk S, Walter C, Ritgen M, Harder L, Martin-Subero Jl, Schroers R, Siemer D, Nuckel H, Dyer MJ, Duhrsen U, Siebert R, Durig J, Kuppers R: Trisomy 19 is associated with trisomy 12 and mutated IGHV genes in B-chronic lymphocytic leukaemia. Br J Haematol 2007, 138(2):217-220.

14. Cuneo A, Rigolin GM, Bigoni R, De Angeli C, Veronese A, Cavazzini F, Bardi A, Roberti MG, Tammiso E, Agostini P, Ciccone M, Della Porta M, Tieghi A, Cavazzini L, Negrini M, Castoldi G: Chronic lymphocytic leukemia with $6 \mathrm{q}$ - shows distinct hematological features and intermediate prognosis. Leukemia 2004, 18(3):476-483.

15. Tsimberidou AM, Wen $S$, O'Brien S, McLaughlin P, Wierda WG, Ferrajoli A, Faderl S, Manning J, Lerner S, Mai CV, Rodriguez AM, Hess M, Do KA, Freireich EJ, Kantarjian HM, Medeiros LJ, Keating MJ: Assessment of chronic lymphocytic leukemia and small lymphocytic lymphoma by absolute lymphocyte counts in 2,126 patients: 20 years of experience at the University of Texas M.D. Anderson Cancer Center. J Clin Oncol 2007, 25(29):4648-4656.

16. Forconi F, Rinaldi A, Kwee I, Sozzi E, Raspadori D, Rancoita PM, Scandurra M, Rossi D, Deambrogi C, Capello D, Zucca E, Marconi D, Bomben R, Gattei V, Lauria F, Gaidano G, Bertoni F: Genome-wide DNA analysis identifies recurrent imbalances predicting outcome in chronic lymphocytic leukaemia with 17p deletion. Br J Haematol 2008, 143(4):532-536.

17. Byrd JC, Stilgenbauer S, Flinn IW: Chronic lymphocytic leukemia. Hematology Am Soc Hematol Educ Program 2004, 163-183.

18. Van Dyke $\mathrm{DL}:+18$ or trisomy 18 in lymphoproliferative disorders.[http:// AtlasGeneticsOncology.org/Anomalies/Tri18ID2030.html].

19. Grubor V, Krasnitz A, Troge JE, Meth JL, Lakshmi B, Kendall JT, Yamrom B, Alex G, Pai D, Navin N, Hufnagel LA, Lee YH, Cook K, Allen SL, Rai KR, Damle RN, Calissano C, Chiorazzi N, Wigler M, Esposito D: Novel genomic alterations and clonal evolution in chronic lymphocytic leukemia revealed by representational oligonucleotide microarray analysis (ROMA). Blood 2009, 113(6):1294-1303.

20. Sargent $R$, Jones D, Abruzzo LV, Yao H, Bonderover J, Cisneros M, Wierda WG, Keating MJ, Luthra R: Customized oligonucleotide array-based comparative genomic hybridization as a clinical assay for genomic profiling of chronic lymphocytic leukemia. J Mol Diagn 2009, 11(1):25-34

21. Hagenkord JM, Monzon FA, Kash SF, Lilleberg S, Xie Q, Kant JA: Arraybased karyotyping for prognostic assessment in chronic lymphocytic leukemia: performance comparison of Affymetrix 10K2.0, 250K Nsp, and SNP6.0 arrays. J Mol Diagn 2010, 12(2):184-196.

22. Dahabreh IJ, Giannouli S, Gota V, Voulgarelis M: GSTT1 and GSTM1 polymorphisms and myelodysplastic syndrome risk: a systematic review and meta-analysis. Int J Cancer 2010, 126(7):1716-1723.

23. Van Dyke DL, Shanafelt TD, Call TG, Zent CS, Smoley SA, Rabe KG, Schwager SM, Sonbert JC, Slager SL, Kay NE: A comprehensive evaluation of the prognostic significance of $13 q$ deletions in patients with Bchronic lymphocytic leukaemia. Br J Haematol 2010, 148(4):544-550.

24. Deveraux QL, Leo E, Stennicke HR, Welsh K, Salvesen GS, Reed JC: Cleavage of human inhibitor of apoptosis protein XIAP results in fragments with distinct specificities for caspases. EMBO J 1999, 18(19):5242-5251.

25. Akagi T, Motegi M, Tamura A, Suzuki R, Hosokawa Y, Suzuki H, Ota H, Nakamura S, Morishima Y, Taniwaki M, Seto M: A novel gene, MALT1 at $18 \mathrm{q} 21$, is involved in $\mathrm{t}(11 ; 18)(\mathrm{q} 21 ; \mathrm{q} 21)$ found in low-grade B-cell lymphoma of mucosa-associated lymphoid tissue. Oncogene 1999, 18(42):5785-5794.

26. Kanduri M, Tobin G, Aleskog A, Nilsson K, Rosenquist R: The novel NF[kappa]B inhibitor IMD-0354 induces apoptosis in chronic lymphocytic leukemia. Blood Cancer Journal 2011, 1:e12.

27. Gunn SR, Hibbard MK, Ismail SH, Lowery-Nordberg M, Mellink CH, Bahler DW, Abruzzo LV, Enriquez EL, Gorre ME, Mohammed MS, Robetorye RS: Atypical 11q deletions identified by array CGH may be missed by FISH panels for prognostic markers in chronic lymphocytic leukemia. Leukemia 2009, 23(5):1011-1017.

28. Dessen P, Le Minor S: GSTT1 (glutathione S-transferase theta 1).[http:// atlasgeneticsoncology.org/Genes/GC_GSTT1.html].

29. Yuille M, Condie A, Hudson C, Kote-Jarai Z, Stone E, Eeles R, Matutes E, Catovsky D, Houlston R: Relationship between glutathione S-transferase $\mathrm{M} 1, \mathrm{~T} 1$, and $\mathrm{P} 1$ polymorphisms and chronic lymphocytic leukemia. Blood 2002, 99(11):4216-4218.

30. Gunn SR, Bolla AR, Barron LL, Gorre ME, Mohammed MS, Bahler DW, Mellink CH, van Oers MH, Keating MJ, Ferrajoli A, Coombes KR, Abruzzo LV, Robetorye RS: Array CGH analysis of chronic lymphocytic leukemia reveals frequent cryptic monoallelic and biallelic deletions of chromosome 22q11 that include the PRAME gene. Leuk Res 2009, 33(9):1276-1281.

31. Okazaki N, Takahashi N, Kojima S, Masuho Y, Koga H: Protocadherin LKC, a new candidate for a tumor suppressor of colon and liver cancers, its association with contact inhibition of cell proliferation. Carcinogenesis 2002, 23(7):1139-1148.

32. Georgantas RW, Hildreth R, Morisot S, Alder J, Liu CG, Heimfeld S, Calin GA, Croce CM, Civin Cl: CD34+ hematopoietic stem-progenitor cell microRNA expression and function: a circuit diagram of differentiation control. Proc Natl Acad Sci USA 2007, 104(8):2750-2755.

33. Holzelova E, Vonarbourg C, Stolzenberg MC, Arkwright PD, Selz F, Prieur AM, Blanche S, Bartunkova J, Vilmer E, Fischer A, Le Deist F, Rieux- 
Laucat F: Autoimmune lymphoproliferative syndrome with somatic Fas mutations. N Engl J Med 2004, 351(14):1409-1418.

34. Dunphy WG, Kumagai A: The cdc25 protein contains an intrinsic phosphatase activity. Cell 1991, 67(1):189-196.

35. Altekruse SF, Kosary CL, Krapcho M, Neyman N, Aminou R, Waldron W, Ruhl J, Howlader N, Tatalovich Z, Cho H, Mariotto A, Eisner MP, Lewis DR, Cronin K, Chen HS, Feuer EJ, Stinchcomb DG, Edwards BK: SEER Cancer Statistics Review, 1975-2007.[http://seer.cancer.gov/csr/1975_2007/].

36. Mauro FR, Foa R, Giannarelli D, Cordone I, Crescenzi S, Pescarmona E, Sala R, Cerretti R, Mandelli F: Clinical characteristics and outcome of young chronic lymphocytic leukemia patients: a single institution study of 204 cases. Blood 1999, 94(2):448-454

doi:10.1186/1755-8166-4-25

Cite this article as: Kolquist et al:: Evaluation of chronic lymphocytic leukemia by oligonucleotide-based microarray analysis uncovers novel aberrations not detected by FISH or cytogenetic analysis. Molecular Cytogenetics 2011 4:25.

\section{Submit your next manuscript to BioMed Central} and take full advantage of:

- Convenient online submission

- Thorough peer review

- No space constraints or color figure charges

- Immediate publication on acceptance

- Inclusion in PubMed, CAS, Scopus and Google Scholar

- Research which is freely available for redistribution

Submit your manuscript at www.biomedcentral.com/submit 